SGaw after ipratropium bromide than after salbutamol but the difference was not significant. The combination of the two drugs produced a slightly greater and longer response than either alone, but the effect was not significant. Neither drug has any more effect on pulse rate or blood pressure than placebo. The mean results of the atropine tests differed significantly between the bronchitic $(85.4 \%)$ and the asthmatic groups $(47.4 \%$; $P<0.01$ ).

\section{Discussion}

These results show that both salbutamol and ipratropium bromide have a pharmacological bronchodilator action in asthmatic and bronchitic patients. The effect of salbutamol is significantly greater in asthmatic patients, however, than in bronchitic patients. In asthmatic subjects Lahdensuo et al. (1973) found a larger mean increase in peak expiratory flow after salbutamol than after ipratropium bromide. In spite of the fact that the atropine test clearly separated the asthmatic and bronchitic patients, suggesting that bronchitics respond better to anticholinergic than to beta-adrenergic stimulant drugs, there was no significant difference in the responses of the bronchitic patients to either drug. This may be because bronchitic patients respond less well to bronchodilator drugs in general, and therefore differences in response are harder to prove. Possibly the two drugs might be effective in different patients but since the response to ipratropium bromide and salbutamol was highly correlated this did not seem to be the case. The atropine test separated well patients with non-allergic and allergic airway obstruction. It did not give an indication, however, of the individual response of the patient to the drugs. The combination of the two drugs produced a slightly greater and more prclonged response than either alone.

In conclusion, in asthma salbutamol aerosol is more effective than ipratropium bromide whereas both drugs have a comparable bronchodilation effect in bronchitics.

We thank Professor David Kerridge for statistical advice and Boehringer Ingleheim Ltd. for supplying ipratropium bromide.

Requests for reprints should be addressed to Dr. K. N. V. Palmer, University Department of Medicine, Foresterhill, Aberdeen AB9 2ZD.

\section{References}

Altounyan, R. E. C. (1964). Thorax, 19, 406.

Altounyan, R. E. C. (1966). Proceedings of the Royal Society of Medicine,

59, Suppl., p. 56.

Crompton, G. K. (1968). Thorax, 23, 46 .

Guyatt, A. R., and Alpers, J. H. (1968). Fournal of Applied Physiology, 24, 310

Lahdensuo, A., Viljanen, A. A., and Muittari, A. (1973). Scandinavian fournal of Clinical and Laboratory Investigation, 31, Suppl No. 130, 16. Medical Research Council (1965). Lancet, 1, 775.

Poppius, H., and Salorinne, Y. (1973). British Medical fournal, 4, 134.

\title{
Depression of Bone Marrow Colony Formation in Gold-induced Neutropenia
}

\author{
A. HOWELL, J. M. GUMPEL, R. W. E. WATTS
}

British Medical fournal, 1975, 1, 432-434

\section{Summary}

Bone marrow culture in semi-solid agar was used to assess the proliferative activity and the response to sodium aurothiomalate of the myeloid precursor cells from patients during and after recovery from neutropenia associated with the use of this drug. Colony formation was reduced during the neutropenia and returned to normal after recovery. The rheumatoid process itself did not impair colony formation even in patients with Felty's syndrome. Sodium aurothiomalate inhibited colony formation by normal marrow in a dosedependent manner. Bone marrow colonies from patients who had recovered from neutropenia induced by sodium aurothiomalate were not abnormally sensitive to the inhibitory effect of the drug in vitro. The metabolism of gold is probably altered in a small proportion of patients, which causes high local concentrations within the bone marrow leading directly to marrow depression.

\footnotetext{
Division of Inherited Metabolic Diseases, M.R.C. Clinical Research Centre, Northwick Park Hospital, Middlesex HA1 3UJ

A. HOWELL, M.B., M.R.C.P., Member of Scientific Staff

R. W. E. WATTS, M.D., P.R.C.P., Head of Division
}

Rheumatology Unit, Northwick Park Hospital, Middlesex HA1 3UJ J. M. GUMPEL, B.M., M.R.C.P., Consultant Physician

\section{Introduction}

Idiosyncratic agranulocytosis and neutropenia may be caused by a variety of therapeutic agents, and from the limited data on the mechanism of agranulocytosis Pisciotta (1973) proposed a classification into two types. Type I, best exemplified by amidopyrine sensitivity, occurs shortly after ingestion of a little drug in a patient sensitized by its previous administration and causes a precipitous decline in the neutrophil count. Leucoagglutinins are found, there is immunological destruction of peripheral neutrophils. Type II reactions differ: they occur during continuous treatment with a drug and are associated with bone marrow depression and interference with granulocyte production. Reintroduction of the drug after recovery does not cause immediate decline of neutrophils. Pisciotta (1973) suggested that this type of agranulocytosis is secondary to a specific biochemical defect in the patient and is best exemplified by chlorpromazine sensitivity, and he has shown that the bone marrow of patients who have recovered from chlorpromazine sensitivity incorporates radioactive precursors into nucleic acids more slowly than control marrow. Colony formation in the agar culture system is decreased and more of the cells are in the $G_{1}$ phase of the cell cycle. He suggests that treatment with chlorpromazine in patients with inherently reduced marrow proliferation results in agranulocytosis.

Bone marrow depression is an uncommon but a serious side effect of gold therapy for rheumatoid arthritis. In one series $27 \%$ of 55 cases of thrombocytopenia, neutropenia, or aplastic anaemia caused by gold salts were fatal (Kay, 1973). Goldinduced neutropenia has many features of a type II reaction: it occurs usually after weeks of therapy with a slow decline of neutrophil numbers, and therapy can often be continued after 
recovery from marrow depression without ill effects. In favour of the hypothesis that this type is associated with a biochemical defect we reported a case in which the patient showed an increased susceptibility to gold inhibition of some of the enzymes which catalyse the early steps on the pyrimidine biosynthetic pathway during an episode of gold-induced neutropenia (Westwick et al., 1974). These enzymes were no longer sensitive when the patient recovered. Denman and Denman (1968), however, suggested that gold-induced bone marrow depression is mediated immunologically because of increased blast transformation of lymphocytes in the presence of gold in affected patients.

We have used the technique of bone marrow culture in semisolid agar to assess the proliferative activity and the response to sodium aurothiomalate of myeloid precursors from patients during and after recovery from neutropenia to test the hypothesis that there is a biochemical defect in bone marrow cells of patients with gold-induced neutropenia.

\section{Patients and Methods}

Bone marrow was obtained by sternal puncture from four groups of patients who fulfilled the American Rheumatism Association criteria for definite or classified rheumatoid arthritis (see table). Three had gold-induced neutropenia, three had never been neutropenic (two were receiving gold medication), three had Felty's syndrome, and five patients, two of whom (cases 1 and 2) were tested when neutropenic, had recovered from neutropenia. Thirty non-rheumatoid control specimens were obtained from normal volunteers or from ribs removed at thoracotomy for benign and malignant conditions but with normal marrow smears. Differential counts of the bone marrow of the three neutropenic patients showed that there was no significant haemodilution of the marrow specimens.

These investigations were approved by the Northwick Park Hospital and Clinical Research Centre ethical committee and informed consent for sternal puncture was obtained from all subjects. Biopsies on patients other than for clinical indications were usually performed under general anaesthesia during elective surgery for rheumatoid arthritis.

Bone marrow was cultured using a modification (Howell et al., 1974) of the technique of Pike and Robinson (1970). Bone marrow cells $\left(2 \times 10^{5}\right)$, were suspended in semi-solid agar on a hard agar underlay containing $10^{6}$ human peripheral blood leucocytes. Leucocytes are a source of colony-stimulating factor, which is a glycoprotein vital for the proliferation of bone marrow precursors in the overlay. We obtained leucocytes from normal human volunteers, as outlined previously (Howell et al., 1974). Many cultures were performed using leucocytes from two or three donors in separate plates; the difference in stimulating activity between donors was never more than $10 \%$. Over 10 days' incubation the precursor cells divide and differentiate to form colonies of granulocytes and monocytes. The number of colonies containing more than 50 cells was counted using a dissecting microscope.

Sodium aurothiomalate (Myocrisin) was made up as a $10-\mathrm{mM}$ solution in phosphate buffered saline (P.B.S.) (pH 7.4, $\mathrm{NaCl} 138$ $\mathrm{mmol} / \mathrm{l}, \mathrm{KCl} 3 \mathrm{mmol} / \mathrm{l}, \mathrm{Na}_{2} \mathrm{HPO}_{4} 8 \mathrm{mmol} / \mathrm{l}$, and $\left.\mathrm{KH}_{2} \mathrm{PO}_{4} 2 \mathrm{mmol} / \mathrm{l}\right)$ and dilutions made in P.B.S. The drug $(100 \mu \mathrm{l})$ or P.B.S. as control was added to each Petri dish before adding the two agar layers. All observations were performed at least in triplicate. Experiments with sodium ${ }^{105} \mathrm{Au}$-aurothiomalate (Radiochemical Centre, Amersham) showed that the drug was uniformly distributed in the upper and lower agar layers within six hours. The same batch of fetal bovine serum for assessment of proliferation was used throughout. All doseresponse curves were performed using human $\mathrm{AB}$ serum rather than fetal bovine serum because of differences in inhibition between these two types of sera (Howell et al., 1973). Dose-response curves were analysed by the probit method as previously described (Howell et al, 1974).

\section{Results}

Colony formation was appreciably reduced in all three patients during gold-induced neutropenia and returned to normal in the two patients we were able to retest after recovery (fig. 1). Colony formation was also normal in three other patients who had recovered from neutropenia and in six rheumatoid controls, including three patients with Felty's syndrome.

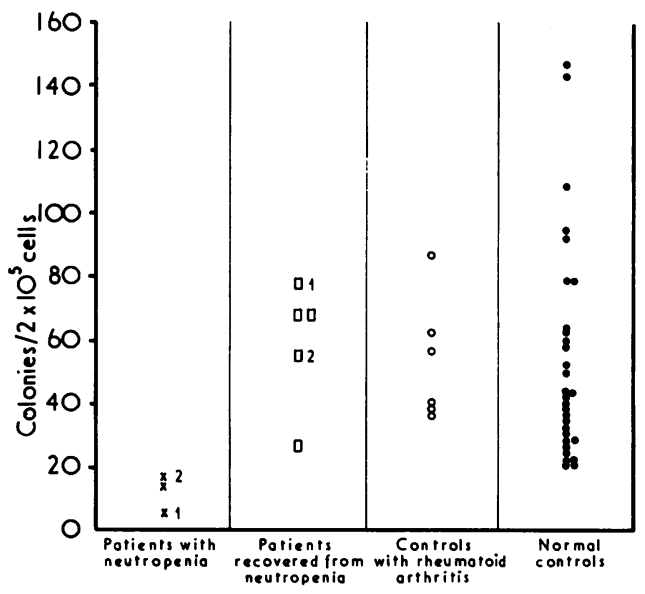

FIG. 1-Colony formation in patients and controls. Two patients (cases 1 and 2) tested during and after recovery from neutropenia are indicated.

Details of Neutropenic Patients and Controls with Rheumatoid Arthritis

\begin{tabular}{|c|c|c|c|c|c|c|c|}
\hline $\begin{array}{l}\text { Case } \\
\text { No. }\end{array}$ & $\begin{array}{c}\text { Age } \\
\text { (Years) }\end{array}$ & $\underset{(\mathrm{g} / \mathrm{dl})}{\text { Haemoglobin }}$ & $\underset{\left(\times 10^{\circ} / 1\right)}{\text { W.B.C. }}$ & $\begin{array}{l}\text { Neutrophils* } \\
\left(\times 10^{\circ} / 1\right)\end{array}$ & $\begin{array}{l}\text { Lowest Neutrophils } \\
\qquad\left(\times 10^{\circ} / 1\right)\end{array}$ & $\begin{array}{c}\text { Total Dose of } \\
\text { Sodium Aurothiomalate } \\
(\mathrm{mg})\end{array}$ & Other Drugs \\
\hline $\begin{array}{l}1 \\
2 \\
3\end{array}$ & $\begin{array}{l}48 \\
33 \\
67\end{array}$ & $\begin{array}{l}11 \cdot 8 \\
10 \cdot 8 \\
12 \cdot 9\end{array}$ & $\begin{array}{l}2 \cdot 9 \\
3 \cdot 4 \\
1 \cdot 7\end{array}$ & $\begin{array}{l}\text { Patients with Gol } \\
1.97(5) \dagger \\
1.87(17)+ \\
0.799(3)+\end{array}$ & $\begin{array}{c}\text { d-induced Neutropenia } \\
1 \cdot 84 \\
0 \cdot 77 \\
0.28\end{array}$ & $\begin{array}{r}1270 \\
160 \\
2570\end{array}$ & $\begin{array}{l}\text { Aspirin } \\
\text { Aspirin, ferrous sulphate } \\
\text { Aspirin, chlordiazepoxide, } \\
\text { cloxacillin, prednisone }\end{array}$ \\
\hline $\begin{array}{l}1 \\
2 \\
4\end{array}$ & $\begin{array}{l}48 \\
33 \\
66\end{array}$ & $\begin{array}{r}12 \cdot 2 \\
9 \cdot 8 \\
13 \cdot 5 \\
\\
12 \cdot 1\end{array}$ & $\begin{array}{l}4 \cdot 6 \\
4 \cdot 9 \\
7 \cdot 2\end{array}$ & $\begin{array}{c}\text { Patients Recovered fro } \\
3.86 \\
3.23 \\
5.62 \\
\\
3.21\end{array}$ & 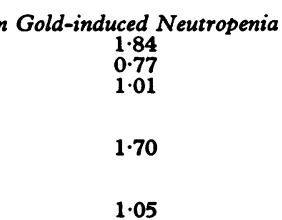 & $\begin{array}{r}1270 \\
160 \\
1350 \\
110 \\
\\
\\
260\end{array}$ & $\begin{array}{l}\text { Aspirin, Distalgesic } \\
\text { Ferrous sulphate } \\
\text { Aspirin, amitriptyline, } \\
\text { digitoxin, frusemide, } \\
\text { spironolactone } \\
\text { Prednisolone, ferrous } \\
\text { sulphate, Panadeine Co, } \\
\text { indomethacin } \\
\text { Aspirin }\end{array}$ \\
\hline 7 & 64 & $11 \cdot 1$ & $7 \cdot 7$ & \multicolumn{2}{|c|}{$\begin{array}{ll}\text { 4.64 } & 1.05 \\
\text { Controls with Rheumatoid Arthritis }\end{array}$} & & Hydrocortisone, \\
\hline $\begin{array}{l}8 \\
9\end{array}$ & $\begin{array}{l}49 \\
49\end{array}$ & $\begin{array}{l}13 \cdot 0 \\
13 \cdot 0\end{array}$ & $8 \cdot 7$ & \multirow{2}{*}{ Patients wit } & \multirow{2}{*}{ helty's Syndrome } & $\begin{array}{r}500 \\
1510\end{array}$ & $\begin{array}{l}\text { cotrimoxazole } \\
\text { Indomethacin, aspirin } \\
\text { Indomethacin, aspirin }\end{array}$ \\
\hline $\begin{array}{l}10 \\
11 \\
12\end{array}$ & $\begin{array}{l}62 \\
65 \\
50\end{array}$ & $\begin{array}{l}10 \cdot 9 \\
12 \cdot 0 \\
13 \cdot 3\end{array}$ & $\begin{array}{l}1 \cdot 2 \\
1 \cdot 1 \\
2 \cdot 6\end{array}$ & & & & $\begin{array}{l}\text { Vitamins } A \text { and } D \text {, calcium } \\
\text { Prednisolone } \\
\text { Aspirin }\end{array}$ \\
\hline
\end{tabular}

* Neutrophil count at time of marrow biopsy. Neutrophil counts in cases 1 and 2 are much less than all previous regular counts on these patients. $\dagger$ Numbers in parentheses are numbers of weeks between lowest neutrophil count and marrow biopsy. 
Sodium aurothiomalate inhibited colony formation by normal bone marrow in a dose-dependent manner (fig. 2) and $50 \%$ inhibition $\left(\mathrm{ED}_{50}\right)$ of colony formation occurred at concentrations between 8 and $30 \mu \mathrm{mol} / 1$ (312 and $1170 \mu \mathrm{g} / 100 \mathrm{ml}$ ). Doseresponse curves were prepared using bone marrow from three patients who had recovered from gold-induced neutropenia and five non-rheumatoid controls. There was no significant difference in the $\mathrm{ED}_{50}$ between these two groups (fig. 3). The probit analysis regression lines from the eight experiments were parallel, indicating that the $\mathrm{ED}_{50}$ was adequate for expressing the results. We were unable to test the sensitivity of marrow cells to gold in our three patients at the time of neutropenia because of the low colony formation.

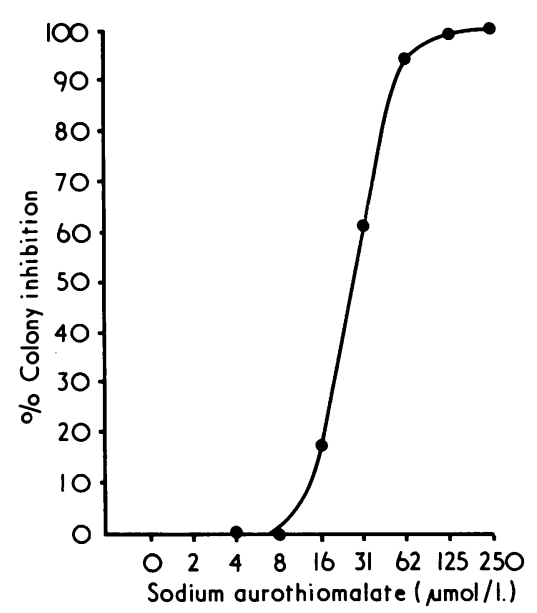

FIG. 2-A typical dose-response curve for inhibition of colony formation by sodium aurothiomalate. Conversion: SI to Traditional Units-Sodium aurothiomalate: $1 \mu \mathrm{mol} / \mathrm{l} \approx 39 \mu \mathrm{g} / 100 \mathrm{ml}$.

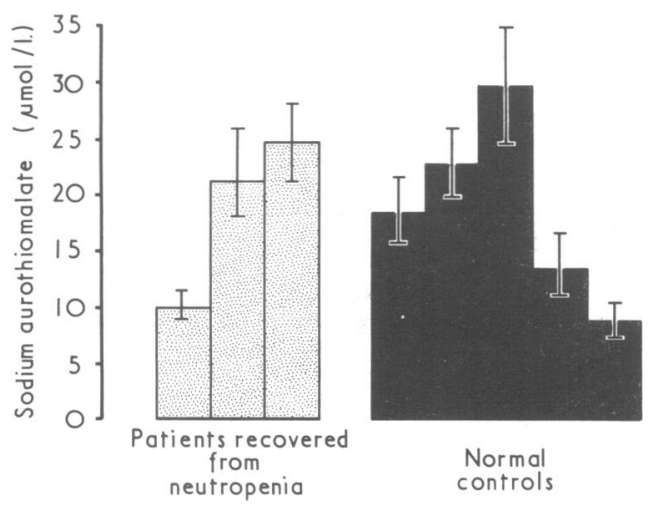

FIG. 3- $\mathrm{ED}_{50}$ for sodium aurothiomalate inhibition of colony formation in three patients after recovery from gold-induced neutropenia and five norma controls. Bars represent $95 \%$ fiducial limits of
estimate of $\mathrm{ED}_{50}$.

\section{Discussion}

We have shown that bone marrow colony formation is reduced during gold-induced neutropenia and returns to normal after recovery. Low colony formation has been recorded in other drug-induced neutropenias and in aplastic anaemia (Greenberg and Schrier, 1973; Kurnick et al., 1971). In cyclic neutropenia colony formation is high during the neutropenic phase when there is a considerable marrow proliferation and is reduced at peak neutrophil counts when marrow proliferation is diminished (Greenberg and Schrier, 1973). These observations independently support the view that the agar culture technique can be used to assess the proliferative activity of bone marrow. Reduced colony formation in gold-induced neutropenia may therefore be due to either direct or indirect myeloid depression by gold. The bone marrow differential counts on these patients indicate that an adequate marrow sample had been obtained and that gross dilution with peripheral blood during aspiration was an unlikely cause of the low colony formation.

Pisciotta (1973) found that colony formation was low in marrow taken from patients after recovery from chlorpromazine-induced agranulocytosis and suggested that their marrow had intrinsically low proliferative activity. This was not so in our patients because those who could be tested after recovery showed normal colony formation. Also, the cells from these patients were not abnormally sensitive to gold as their dose-response curves of colony formation against sodium aurothiomalate concentration were similar to those of controls.

Gold accumulates in tissues during treatment, and concentrations far greater than those required to inhibit colony formation in vitro are found in bone marrow (Gottlieb et al., 1972). Presumably this gold is protein-bound and toxicologically inactive. Toxicity could occur if tissue binding of gold was reduced or if there was an altered distribution, of gold within tissues. Evidence for variable distribution of gold has been reported. Smithet al.(1973) found gold in both red blood cells and serum in $40 \%$ of their patients but in serum only in the remaining $60 \%$. After injection several days elapsed before gold appeared in red blood cells, and they concluded that the incorporation of gold was at the stage of erythroid cell differentiation in some patients. It remains to be seen if these differences in gold transport into bone marrow precursor cells are associated with toxicity.

Our results show that gold depresses myeloid proliferation in vivo and in vitro and also that there was no detectable abnormality of the myeloid cells in patients who had recovered from gold-induced neutropenia. We suggest that the metabolism of gold is altered in a small proportion of patients and this causes high local gold concentrations within the bone marrow, leading directly to marrow depression.

We thank Dr. April Kay and Dr. A. G. Mowat for permission to study patients under their care, the surgeons and theatre staff of Colindale and Northwick Park Hospitals for help with collection of specimens, and the staff of the haematology department at Northwick Park Hospital for blood count data. We are indebted to Miss Susan Chinn for her statistical advice and to May and Baker Ltd. for supply of sodium aurothiomalate.

A. Howell was in receipt of a Medical Research Council Fellowship.

\section{References}

Denman, E. J., Denman, A. M. (1968). Annals of Rheumatic Diseases,

Gottlieb, N. L., Smith, P. M., Smith, E. M. (1972). Arthritis and Rheumatism, $15,16$.

Greenberg, P. L., and Schrier, S. L. (1973). Blood, 41, 753.

Howell, A., Andrews, T. M., and Watts, R. W. E. (1973). British Medical Fournal, 2, 48.

Howell, A.- et al. (1974). Clinical Science and Molecular Medicine, 46, 619. Kay, A. (1973). Annals of Rheumatic Diseases, 32, 277.

Kurnick, J. E., Robinson, W. A., Dickey, C. A. (1971). Proceedings of the Society for Experimental Biology and Medicine, 137, 917.

Pike, B. L., and Robinson, W. A. (1970). Fournal of Cell Physiology, 76, 77. Pisciotta, A. V. (1973). Seminars in Haematology, 10, 279.

Smith, P. M., Smith, E. M., Gottlieb, N. L. (1973). Fournal of Laboratory and Clinical Medicine, 82, 930.

Westwick, W. J., et al. (1974). Quarterly fournal of Medicine, 43, 231. 